\title{
Responses to Internal Displacement in Colombia: Guided by What Principles?
}

\author{
Ellen Fadnes and Cindy Horst
}

\section{Abstract}

This article aims to explain the gap between IDP law and practice in Colombia. Colombia's IDP legislation is considered one of the world's most advanced legal systems as it puts in practice the UN Guiding Principles on Internal Displacement. However, the reality of life for IDPs in Colombia does not match their legal rights. Especially the sections of the law related to preventing displacement and providing durable solutions for IDPs are poorly implemented. Following Ferguson's work on depoliticization, we argue that displacement in Colombia is treated as a technical rather than political problem, detaching it from root causes like landownership and structural class inequalities. This article provides an overview of the root causes and analyzes the different methods through which internal displacement is "depoliticized" in Colombia. In conclusion, we will discuss the wider implications of the Colombian case for understanding implementation challenges of the Guiding Principles.

\section{Résumé}

Cet article tente d'expliquer l'écart entre le droit des personnes déplacés internes et sa mise en application en Colombie. Le droit colombien en matière de déplacement interne est considéré comme l'un des systèmes juridiques les plus avancés au monde en ce qu'il met en pratique les Principes directeurs relatifs au déplacement de personnes à l'intérieur de leur propre pays des Nations Unies. Cependant, la réalité des personnes déplacées en Colombie ne correspond pas à leurs droits. En particulier, les sections de la loi relatives à la prévention des déplacements et à la mise en place de solutions durables pour les déplacés internes sont mal mises en cuvre. Suivant les travaux de Ferguson sur la dépolitisation, nous soutenons que le déplacement en
Colombie est considéré comme un problème technique plutôt que politique, le détachant de ses causes premières telles la propriété foncière et les inégalités structurelles de classe. Nous donnons un aperçu des causes premières du déplacement et analysons les différentes méthodes par lesquelles le déplacement interne est "dépolitisé » en Colombie. En conclusion, nous discutons des implications plus larges $d u$ cas colombien pour la compréhension des défis de mise en œuvre des Principes directeurs.

\section{Introduction}

In this article, we will analyze displacement in Colombia to illustrate some of the challenges faced in the implementation of the UN Guiding Principles on Internal Displacement. In the case of Colombia, one main concern is that the response to internal displacement has effectively depoliticized the causes and consequences of the displacement. Forced internal displacement in Colombia has been going on for decades, causing millions of Colombians to abandon their homes and seek refuge in neighbouring towns or large cities. $^{1}$ Today, Colombia hosts one of the world's largest IDP populations, and the UN has identified the situation in the country to be the worst humanitarian crisis in the Western hemisphere. ${ }^{2}$ Yet the phenomenon only received attention after the mid-1990s, when the Colombian government officially acknowledged their responsibility and first steps towards the formulation of IDP rights were taken. The framework for IDP-related policies is provided by Law 387, which was passed in Congress in 1997. Currently, displacement-related laws in Colombia are heralded as the most progressive and comprehensive attempt to implement the Guiding Principles. ${ }^{3}$

Forced displacement in Colombia has commonly been explained by the severe and extensive political violence involving a number of armed actors, including paramilitaries, guerrillas, and the national army. Various guerrilla 
groups emerged in the 1960 s as a reaction to systematic oppression and marginalization of the rural and poor population throughout centuries, with the most important being the FARC (Fuerzas Armadas Revolucionarias de Colombia, or Revolutionary Armed Forces of Colombia) and ELN (Ejercito de Liberación Nacional, or the National Liberation Army). Whereas the first, which is claimed to be the largest and best organized guerrilla movement in Latin America today, was initiated by peasants, the second was organized by students and intellectuals inspired by the Cuban revolution. Paramilitary organizations emerged as the right-wing counter-insurgency, aiming to fight back the guerrillas and protect rich landowners and drug lords. Decades of struggle by the various armed groups for power and legitimacy have included brutal violence and massacres, with severe consequences for civilians. However, as we will illustrate, it is far too simplistic to explain forced displacement in Colombia as a random side effect of the clashes between armed groups without recognizing underlying political causes.

We argue that responses to displacement in Colombia have effectively depoliticized the situation, removing attention away from these and other political factors. This is done through practices that treat the conditions of the displaced as problems that require technical rather than structural or political solutions. Depoliticizing practices include a focus on humanitarian aid rather than prevention of displacement and durable solutions for the displaced, a governmental perspective that only acknowledges certain causes for displacement while denying others, and an invisibility of the displaced in the public debate on the Colombian conflict. In Colombia, many of the internally displaced are not recognized as IDPs and the remainder are then reduced to recipients of humanitarian assistance and not linked to the political conflict in the public debate. This enables an engagement with displacement in Colombia without connecting it to its underlying causes. In this article, we will draw on theorizing on depolitization as developed by Ferguson and Malkki. ${ }^{4}$

The data on which our argument is based was collected during fieldwork in Bogotá, Colombia, from June to August 2007, supplemented with a review of secondary sources. Interviews were conducted with representatives from displaced communities, civil society, and responsible state entities. A government-organized conference marking the ten years of the Colombian IDP law was attended, and participant observation also took place in IDP registration centres. A wide range of legal documents were collected, including the Colombian IDP law, the UN Guiding Principles on Internal Displacement, and verdicts and rulings from the Constitutional Court in Colombia. Furthermore, official documents from state entities and reports from NGOs and the UN were consulted. After providing a brief background to the conflict, the article first describes the discrepancy between law and practice in Colombia. The second section analyzes the different methods through which internal displacement is "depoliticized" in Colombia. In the conclusion, we will summarize our observations from the Colombian case in order to look at their implications for the protection of internally displaced people elsewhere.

\section{Background to Displacement in Colombia}

Latin America is known for its immense gap between social classes, as wealth and landownership have been concentrated throughout history in most parts of the continent. The income distribution was probably the worst in the world in the 1960s, and has amplified during the last half of the twentieth century, culminating in the neo-liberal era of the 1980s and 1990s. ${ }^{5}$ The high concentration of landownership which characterizes Latin America has been a catalyst for widespread rural violence and one of the main triggers for the emergence of insurgency movements. ${ }^{6}$ Violence in the rural areas has been endemic and persistent throughout the history of the continent, with the Spanish conquest and colonization as one of the most brutal periods. The agrarian system which emerged in the colonial and post-colonial period, where landowners monopolized territories and established large landed estates, paved the way for the unbalanced and exploitative relationships between land owners and tenants. ${ }^{7}$

In Colombia, the land structure where large haciendas turned the peasantry into oppressed wage workers continued throughout the post-colonial period. The accumulation of land as a source of power and the role of the paramilitaries in protecting the privileges of the landowners in Colombian history has been documented in various sources. ${ }^{8}$ During La Violencia in the 1940s and 1950s, millions of persons were forced to flee their territories, which resulted in an increased concentration of land and ownership of agrarian property. ${ }^{9} \mathrm{Up}$ to this day, the depopulation of areas is used as a deliberate strategy by the armed groups to strengthen their territorial control and to appropriate agricultural land. The Colombian Commission of Jurists (CCJ) has established that territories that present possibilities for expansion of stockbreeding or extensive extraction of minerals and natural resources coincide with high levels of forced displacement. ${ }^{10}$ The displacement has proven to be more intense in regions well-suited for agriculture or areas rich in minerals. ${ }^{11}$

The right to land is a fundamental necessity for the lives and livelihoods of the rural and often poor sections of society, including indigenous, Afro-Colombian, and other groups vulnerable to displacement. Displaced indigenous persons 
especially face dramatic consequences of forced displacement from their territories, because of the important bonds they have with the earth. Mr. Eugenio Reyes, ${ }^{12}$ who has been displaced from Sierra Nevada de Santa Marta in northern Colombia, mentions access to their land, la madre tierra, as the main issue that the more than eighty different groups of indigenous people are fighting for. According to him, if all actors would respect their legal access to a territory, this would enable indigenous communities to maintain safe and stable livelihoods. The Colombian conflict has a number of intertwined causes but the right to land is one of the major underlying factors. The situation has been called a "veritable guerra de territorio or war for land," 13 and it is clear that this war for land has fundamental impacts on displacement in Colombia and the government's efforts of implementing the IDP law.

The great majority of the IDPs are campesinos, peasants from rural areas, with most often a relatively low degree of education and limited sources of income. As most IDPs end up in the urban centres, their displacement implies a complete change of life and the meeting with a new reality. The relationship between the displaced population and the urban politicians is characterized by mutual suspicion and distrust. The cultural and political differences between the intellectual elite in the urban centres and the displaced persons with origin in rural areas are an important obstacle for these two spheres of society to understand each other. This has deep-rooted historical origins in the institutionalization of feudal relationships between the landowning patron and poor peon and the systematic oppression of indigenous people. This history has great implications for the contemporary situation, and adds challenges to the implementation of the legal IDP framework. ${ }^{14}$

The historian Herbert Tico Braun focuses on the cultural relationship between the political and intellectual elites in the urban areas and their rural clientele. ${ }^{15}$ In the 1950s, while in most other Latin American countries the state sought to incorporate the rural population more thoroughly in the nation, the Colombian political elite rather tried to dissociate themselves from the campesinos. The fact that large sections of the poor rural population never fully obtained their civil and political rights further created a sense of humiliation and exclusion among this population. ${ }^{16}$ The gap between the rural and urban population contributes to explaining the lack of communication between those involved in the Colombian IDP situation. Since Law 387 was passed in Congress more than ten years ago, the encounters between the involved actors have been much more frequent, through meetings, hearings in court, and conferences. However, in many ways very little has changed, as Rosa Aguilar, a Kankuamo woman from la Guarjira, stresses when she explains her feelings on the government-organized conference marking the ten years of the Colombian IDP law:

Today, Law 387 is 10 years old, but for us, the indigenous people of Colombia, this is not a celebration. At this conference, we wanted to inform the high officers of this country about our situation, but they are not even present. That shows a lack of respect for our culture and identity as indigenous people, as women, as Africans, and especially as those who have lived through the violence in this country. ${ }^{17}$

Rather than being a random side effect, forced displacement in Colombia is closely linked to struggles for land ownership, and armed actors use attacks on civilians as a deliberate strategy to seize and control land and to weaken other armed groups fighting for the same territory. What complicates the Colombian conflict and violence even more is that the government itself must be considered a perpetrator. The national army has been involved in attacks causing displacement, and investigations by Colombian control authorities and courts have proven close ties between central politicians and paramilitary groups. According to the Colombian weekly Semana, sixty-eight members of Congress were under investigation and thirty-one arrested in the month of April 2008 alone. ${ }^{18}$ Moreover, the political elite and decision makers are themselves often powerful land owners, with little interest in redistribution of land. In light of these facts, it is interesting to study the implementation of the laws that have been put in place to protect the displaced.

\section{Mind the Gap: IDP-Related Law and Practice in Colombia}

Colombia's legislation on internal displacement was developed from 1994, after an announcement by Francis Deng, the representative of the UN Secretary-General on Internally Displaced Persons. The Colombian government, together with a large group of NGOs, had invited Mr. Deng to Colombia to meet with various representatives from the state and civil society. ${ }^{19}$ As Walter Kälin, the present UN Secretary-General on Internally Displaced Persons, has pointed out, "Colombia has a long legal tradition, with a history of excellent legal scholarship and institutions dating from independence." 20 This benefited the development of Law 387, which was passed in 1997 and is applauded as one of the most progressive and comprehensive legal frameworks on internal displacement.

The approval of the law gave juridical basis to subsequent national action on behalf of internal displacement, and the National Plan for Integral Attention of Displaced Persons (SNAIPD) now constitutes the institutional framework for IDP protection. In line with the Guiding Principles 
on Internal Displacement, which were under development when Law 387 was passed in Congress, the Colombian displacement legislation addresses all stages of displacement, including prevention of displacement; humanitarian assistance during displacement; and the right to return to the place of origin or permanently settle elsewhere. It explicitly confirms that it is the duty of the Colombian state to "formulate policies and adopt measures for the prevention of forced displacement, and for assistance, protection, socioeconomic consolidation and stabilization of persons internally displaced by violence." 21

The legislation on displacement profited from the new Colombian Constitution that was introduced in 1991, which makes several references to human rights and creates a number of valuable mechanisms for the protection of civilians in general and the displaced population specifically. ${ }^{22}$ For example, the important petition procedure tutela was introduced and enabled Colombian citizens to denounce violations of basic rights and receive a decision within ten days. The tutela is a "complaint that any citizen can bring before any judge in order to seek an immediate judicial injunction against actions or omissions of any public authority that they claim violates their constitutional fundamental rights." 23 The use of tutela has increased rapidly during the last decade, and the numerous petitions coming from displaced individuals since 1997 quickly made the Constitutional Court acknowledge the existence of a humanitarian crisis. ${ }^{24}$

In 2004 the Constitutional Court of Colombia concluded in ruling T-025 that the current assistance and response by the government towards IDPs was unconstitutional, ordering the state to promptly address this issue. ${ }^{25}$ An unconstitutional state of affairs describes a de facto situation, in which by structural causes a large number of citizens-in this case the displaced population-are suffering in their daily lives because of recurrent violations of their constitutional rights. ${ }^{26}$ The alleged lack of action by the government has further been criticized by a number of civil society actors, in addition to the UN Representative on Internal Displacement. ${ }^{27}$ We suggest that prevention of displacement and the right to return or resettle are by far the most neglected areas of implementation. In the following section, we will provide an overview of the legislation and its implementation in the areas of prevention; humanitarian assistance; and durable solutions.

\section{Preventing Displacement}

According to Law 387, article 2, Colombians have the right not to be forcibly displaced. In relation to prevention, the law focuses on early communication of potential risk factors that may cause displacement, in order for the local and national systems to react and supply services before displacement occurs. The law furthermore underlines the importance of educating the general public on humanitarian law and of generating community tolerance, in addition to promoting immediate action from the armed forces on tumults or attacks. The government's responsibilities include the following measures:

1. Stimulate the formation of work groups for prevention and anticipation of the risks that may produce displacement, 2 . Promote community and citizen actions to generate peaceful coexistence, and law enforcement activity against agents of disturbance, 3. Develop actions to avoid arbitrariness and discrimination, and to mitigate the risks to life, personal integrity, and the private property of displaced populations, 4 . Design and execute an International Humanitarian Law Information Plan, and, 5. Advise the municipal and departmental authorities responsible for the development plans so that they include prevention and assistance programs. ${ }^{28}$

Preventing forced displacement in the midst of an internal armed conflict is arguably extremely challenging. The government has never had complete control over the national territory, and a number of armed groups are fighting for resources and political and social legitimacy in large parts of Colombia. An early warning system, Sistema de Alerta Temprana (SAT), has been developed by Acción Social ${ }^{29}$ and coordinated by the Human Rights Ombudsman, but the risk assessment undertaken encompasses only certain armed, illegal actors. This undermines the dynamics of the ongoing conflict, as displacement is also caused by common hostilities and general lawlessness in areas with high criminal activity or as a side effect of activities that are carried out by the government to eradicate illicit crops. ${ }^{30}$

A further severe limitation of the system is that the national army is rarely ready to intervene when a warning is sent out. This has led potential victims to be reluctant to notify the authorities of displacement-related risks, fearing reprisals from armed groups. ${ }^{31}$ In 2006, as an exception to the general unwillingness to respond to conflict risks, the national army did manage to mobilize and react after receiving reports of harassment and possible attacks in the Nariño department. However, instead of protecting civilians caught in the middle of the hostilities, soldiers were sent to protect areas of military importance such as the PanAmerican Highway. ${ }^{32}$ This suggests that Colombia's current military strategy does not focus on the protection of its civilian population from harassment and armed attacks. The fact that the number of displaced persons in Colombia is increasing every year is another indication that governmental efforts to prevent displacement are far from being implemented in accordance with Law 387. 


\section{Humanitarian Assistance}

All displaced persons registered in the official IDP register, the Registro Unico de Población Desplazada (RUPD), are entitled to emergency assistance. It is further the responsibility of civil and military authorities to ensure the safe and free passage of emergency consignments to receiving communities. The law states that:

once displacement takes place, the National Government shall initiate immediate action to guarantee emergency humanitarian assistance with the purpose of relieving, assisting, and protecting the displaced population, and attending to its needs in the areas of food, personal hygiene, supply management, kitchen utensils, psychological and medical assistance, emergency transportation, and temporary housing in appropriate conditions. ${ }^{33}$

Originally, according to the law, the humanitarian aid was limited to three months, which in exceptional cases could be extended for another three months, depending on the conditions and needs of the individuals or households. ${ }^{34}$ However, in April 2007, the Constitutional Court declared this limitation unconstitutional, ${ }^{35}$ thus taking an important step towards ensuring basic needs for IDPs during this critical phase before possible resettlement or return.

After the Constitutional Court in 2004 declared that the government was far from complying with the IDP law, access to humanitarian aid has increased significantly, especially in the capital where most IDPs end up. According to official statistics, nearly 80 per cent of the displaced population have been provided with the three months of basic assistance that they are entitled to. ${ }^{36} \mathrm{~A}$ recent report from the Monitoring Commission for the Public Policies on Internal Displacement $(\mathrm{MCPP})^{37}$ disputes these high numbers and states that only 64 per cent of displaced households registered in the RUPD received emergency aid in 2006, and only 57 per cent in $2007 .{ }^{38}$ Nonetheless, the resources invested in humanitarian aid have increased rapidly since 2004, and over the last five years the national budget for assistance to the displaced has risen from $\$ 80$ million to $\$ 400$ million annually. ${ }^{39}$ Particularly in Bogotá and other large cities, significant distributions of basic assistance are accomplished and the Colombian displaced population has achieved an increased access to humanitarian emergency aid from state institutions.

\section{Return and Resettlement}

Durable solutions for IDPs are crucial to ensure safety and the possibility for sustainable livelihoods. The Colombian state is responsible for assisting and protecting returnees in their reintegration efforts, and if return is not an option other permanent solutions need to be made available. Law
387 specifies that the Colombian Institute for Agrarian Reform (Instituto Colombiano para la Reforma Agraria, INCORA) should "adopt special procedures and programs for the transfer, adjudication, and titling of land in the expulsion and reception zones of populations affected by forced displacement." 40

The rights that are described here are far from reality for the displaced population. Return is problematic due to the state's lack of territorial control in many of the areas where displacement occurs. ${ }^{41}$ Furthermore, there are very few resettlement projects and research suggests that hardly any of them have proven successful. ${ }^{42}$

One of the problems that has added to the difficulty of securing safe return for IDPs is the increasing number of former paramilitaries that are being settled in the areas from which people were forced to flee. An important step in the governmental plan for demobilization of these socalled self-defence groups has been to grant impunity to most paramilitaries who agree to surrender their weapons and provide them with comprehensive assistance for reintegration and resettlement. Former paramilitary soldiers in fact are reported to receive far greater support in return and resettlement than the displaced population. ${ }^{43}$ The challenge of the impunity granted to these individuals leads to a reluctance among IDPs to return to their places of origin, as the perpetrators of their displacement may be settled in the same community.

Similar problems arise in relation to policies linked to the resettlement of the internally displaced. In 2004, the Colombian government granted an area of 17,000 hectares in Carimagua to IDPs. The area was meant to ensure the resettlement of approximately eighty families, allowing them to start up new lives in relatively safe areas. In February 2008 the Colombian newspaper El Tiempo revealed that the land originally given to IDPs to comply with the national IDP law was sold to international companies for the purpose of producing African palm for the production of biofuel and rubber. According to the Minister of Agriculture, the land was not appropriate for small-scale farming. ${ }^{44}$

A report from the Internal Displacement Monitoring Centre (IDMC) underlines how return to certain areas is also blocked because of the production of palm and producers' presumed links with paramilitary forces. ${ }^{45}$ At times, the displacement may have been staged in order to enable such production in the first place. In 1996, for example, the national army led an attack on a guerrilla base in the Chocó region, causing massive displacement of the civilian population and abandonment of large areas. Soon after, private companies cultivating African palm for the production of biofuel established businesses in these territories. The government has financially and politically supported initiatives 
to build such plantations, in order to eradicate illicit drug crops and promote regional development. ${ }^{46}$ It is clear that return under these conditions is highly unlikely.

\section{Internal Displacement: A Technical Problem or No Problem at All?}

From the above, it is clear that the Colombian state is doing little in practice to fulfill its legal responsibilities to the displaced population, except to some extent in terms of shortterm humanitarian relief. The effort invested at this stage of displacement is unquestionably necessary, but should not take place at the cost of far more complex issues like preventing displacement and ensuring secure resettlement or return. In this section, we will analyze the depoliticizing effects of treating displacement as a technical problem by merely or primarily focusing on humanitarian assistance. Furthermore, we will discuss two related processes that similarly disconnect displacement from its political and historical context. These processes include, first, the Colombian government's discourse on the armed conflict which excludes paramilitaries as potential perpetrators, and second, the invisibility of the displaced in the public debate.

Since 2004, financial allocations from the government have increased steadily, leading to the Colombian displaced population receiving increased humanitarian aid. ${ }^{47}$ This is an important step forward in the implementation of Law 387. Emergency aid is vital for the displaced, who are largely moving from rural backgrounds to urban centres, and who are forced to leave their assets behind and have no foreseeable opportunity for income-generating activity. ${ }^{48}$ Humanitarian assistance is also one of the more concrete obligations of the government towards the displaced population, which makes it easier to measure and reach tangible goals compared to the other rights IDPs have. However, there are a number of closely related reasons why a focus on the humanitarian aspects of IDP rights can be problematic. First of all, the emphasis on humanitarian assistance reduces the Colombian government's ability to enforce the IDP law in the areas of prevention, resettlement, and return, as the time and resources that are invested in one area cannot be invested in the other. Second, the choice of focusing on the humanitarian is unfortunate because it is a focus on technical, short-term solutions rather than political, longterm ones. The displaced are helped with this type of assistance in the present, but they are not provided with solutions for the future, nor is displacement of others prevented, so the problem itself is not addressed in any way.

Thirdly, humanitarian interventions tend to be constituted as the opposite of political ones, ${ }^{49}$ portraying the former to be operating separately from any political or cultural context. Relief aid to displaced people purports to be based on a moral kind of "doing good" that denies the fact that processes of displacement as well as assistance provision are always determined by international historical and politicaleconomic factors. ${ }^{50}$ The perception of emergency assistance as "neutral" and based on a humanitarian imperative disguises all possible political intentions and interests. The aid system as an "anti-politics machine" obscures the powerstructured relationships between "givers" and "receivers," by treating the conditions of the displaced as technical rather than structural problems that require practical rather than political solutions. ${ }^{51}$ Furthermore, as Malkki argues, preventive measures do not come easily in the conventional logic of a "humanitarian operation," as they are conceived to be political and thus beyond the realm of the humanitarian. ${ }^{52}$ This excludes the possibility of focusing on the legal obligation to prevent displacement from occurring in the first place.

\section{The Discourse on the Conflict}

When President Alvaro Uribe took office in 2002, his mandate was based on an electoral campaign promising a hardline policy against the guerrillas. FARC is labelled a terrorist group by the Colombian government, which denies them a position as political actors. ${ }^{53}$ By reducing insurgents to "terrorists" and "bandits," the Uribe administration has been able to redefine the contemporary situation. Colombia's High Commissioner for Peace, Luis Carlos Restrepo Ramírez, stated in March 2005: "In Colombia there is no armed conflict, but rather the threat of terrorism." ${ }^{4}$ This has been repeated at various occasions throughout the years of the Uribe administration. A Colombian lawyer and human rights expert suggested, in an interview, that this rhetoric was one of the main obstacles for reaching sustainable peace and one of the core reasons for the failure to implement the comprehensive legal framework on IDPs. ${ }^{5}$

Ties to the United States have been strengthened since Uribe took office, which is reflected in the expansion of Plan Colombia-the US-funded assistance package aimed at eradicating the production of illicit crops and drug trafficking. In light of the US-led "War on Terror," the government discourse is reducing armed actors to terrorists, stripped of any legitimate political objectives. Furthermore, the Uribe government claims that, since 2006, the Colombian paramilitaries are completely demobilized and are no longer agents of displacement. The government argues that it has managed to demobilize approximately 30,000 paramilitaries, and retrieved around 12,000 small arms. ${ }^{56}$ The discourse on the absence of "self-defence groups" such as the paramilitaries, in combination with the discourse on the absence of war, denies certain groups of displaced people access to 
their rights and thus complicates the implementation of the legal framework. A displaced man in Bogotá explains how the assumed non-existence of paramilitary groups could affect one's possibilities to register as displaced and access IDP rights:

If you go to denounce your case of displacement, there are some conditions. If you say that the ones who displaced you were the paramilitaries, they will tell you that they won't accept your declaration, because the paramilitarism was formally ended one and a half year ago. One and a half years ago, the High Commissioner of Peace said that the paramilitarism in Colombia has ended, that they'd buried it.

The Monitoring Commission for the Public Policies on Internal Displacement (MCPP) has proved these claims in the above-mentioned investigation on whether the government was complying with the demands from the 2004 Constitutional Court ruling T-025. The MCPP report revealed that displaced persons who had tried to denounce their displacement as caused by paramilitaries were systematically rejected in the public centres for registration. Thus, the discourse on the non-existence of an armed conflict and the supposed abolishment of paramilitary groups is further contributing to isolate the Colombian humanitarian catastrophe from its political and historical context. By portraying the armed groups as a sphere of society completely detached from state actions, the authorities urge for the sympathy of the general public, arguing that they are all fighting a common enemy. This allows for the usurpation of land to continue and for private companies to continue establishing themselves in areas abandoned by the displaced, complicating efforts of preventing displacement and ensuring safe resettlement.

\section{The Invisibility of the Displaced}

In the above, we have argued that displacement in Colombia is systematically removed from its political context through a focus on humanitarian responsibilities rather than responsibilities for prevention and durable solutions, and through a representation of the conflict that allows only certain groups of displaced access to (some of) their rights. Whereas Ferguson's analysis of how development aid functions as a practice of depoliticizing the question of poverty $^{57}$ is very useful in this respect, Malkki's work adds a crucial dimension by drawing attention to representational practices of the beneficiaries of aid as ahistorical, universal humanitarian subjects. ${ }^{58}$ She shows that, for the aid encounter to be a neutral, apolitical act, the power relations between aid giver and receiver must be rendered invisible. Depolitization through aid practices can only occur because simultaneously, the beneficiaries of aid are made invisible, being reduced to mute victims rather than historical actors. The aid receiver is depicted as someone in need, devoid of agency, who is connected to the aid giver only in humanness rather than through history or the current everyday powerstructured relationships between individuals and groups. Images of refugees and internally displaced people are commonly characterized by helplessness, suffering, and loss. This represents the displaced as a universal mass of victims, abstracted from the specific political and historical context which caused the displacement. ${ }^{59}$

In the case of Colombia, similarly, the displaced population is made invisible. Whereas the Colombian media does report on the armed conflict continuously, this news hardly ever covers displacement and is far from nuanced. The space for critical journalism is highly limited in Colombia because firstly, ownership of mass media is concentrated in the hands of the political elite and secondly, Colombia is one of the most dangerous countries for investigative reporters. ${ }^{60}$ Threats and assassinations by armed groups are most often met with impunity, which makes journalists use a high degree of self-censorship. ${ }^{61}$ As a consequence, displacement is rarely discussed within reporting on the armed conflict. A Human Rights expert who was interviewed indicates, "The displaced population is systematically made invisible. They are overshadowed by the personification of the kidnapped, the corpses of the 'diputados,' humanitarian agreements reached, etcetera (...)." 62

According to this person, the invisibility of the displaced is not a coincidence but a deliberate strategy to remove public attention from the increasing problems related to displacement. But according to many of the displaced themselves, the main reason for their invisibility is the fact that journalists are simply not interested in their predicament. Mr. Andrés Lozano, who is a displaced indigenous man settled in Bogotá, voices this concern when he comments on what he considers to be the mass media's general lack of focus on and interest in the marginalized sections of the population:

Last week during the demonstrations for the hostages, five persons were killed in that same week just outside Bogotá, and no one said anything. In Colombia, you will not hear anything in the media about the displacement and the assassinations of campesinos and of the lower class.

As this statement suggests, among the displaced there is a deep-rooted skepticism towards the political elite, which is seen to include the media as well. As noted above, in Colombian society, there has been a huge gap between the urban elite and the rural population for centuries, a situation which continues until today. Most IDPs are considered 
different culturally and are viewed as campesinos, or peasants, who threaten the nature of urban culture. ${ }^{63}$ This historically located gap is one of the explanations for the processes and practices described here, while these at the same time work towards making the gap invisible.

\section{In Conclusion}

Colombia's legislation on internal displacement is largely modelled on the UN Guiding Principles on Internal Displacement, which were developed at the same time. It is amongst the most comprehensive laws to secure the rights of IDPs due to a combination of international pressure and input as well as a very strong national expertise. Yet, as we have illustrated in this article, the implementation of the law has been very limited, and main achievements have only been made in terms of short-term humanitarian assistance. On the one hand, one may argue that it is crucial for the Colombian state to assist its displaced population and that this assistance is vital in enabling survival of the displaced in the initial, most difficult, phase of their displacement. Furthermore, it is crucial that a comprehensive law is in place and there is some evidence that this is an instrument that the IDPs can increasingly use to improve their situation. The utilization by IDPs of the tutela, for example, has contributed to changes, as authorities are held accountable to their legal obligations under Law 387.

On the other hand, one may also argue that the systems that are currently available to assist IDPs in Colombia effectively cover up the more structural problems underlying their displacement, which are thus left unaddressed both nationally and internationally. In fact, the implementation of the Guiding Principles in national legislation, and partial compliance with this law through the provision of humanitarian assistance of the displaced, may have prevented a public outcry on the situation in Colombia. The question is whether this is specific to the Colombian situation or whether it is common for states suffering from internal displacement to use the IDP category as a humanitarian category in order to avoid having to address the political issues underlying the displacement. While refugees who flee the country and cross a national border may obtain a legal status and protection under the Refugee Convention, this is not the case for IDPs because they are still under the jurisdiction of their own state. ${ }^{64}$ Thus, being an internally displaced person is not a legal status, and imposing the Guiding Principles on any state is impossible because of the salience of territorial sovereignty.

Some argue that the Guiding Principles have been crucial in terms of recasting sovereignty as responsibility 65 or in highlighting the responsibility of the international community when states are unable or unwilling to address internal displacement. ${ }^{66}$ Critical voices on the other hand have argued that the Guiding Principles add nothing to the existing body of international human rights law, as the incorporated rights are already covered by legally binding treaties. IDPs should thus be treated as any other victim of human rights violations, making the IDP category redundant. ${ }^{67}$ The analysis presented here of responses to displacement in Colombia adds a concern to Hathaway's. We argue that the partial implementation of IDP legislation in Colombia and the remaking of the IDP as a humanitarian category facilitates a focus away from human rights violations. It is hardly likely that the Colombian case is unique in this sense.

\section{Notes}

1. Figures are widely disputed and range from government figures of 2.4 million to figures produced by the Consultancy on Human Rights and Displacement (CODHES) of 4 million.

2. UN News Centre, "Colombia has biggest humanitarian crisis in Western Hemisphere," news release, May 5, 2004.

3. UNHCR, "Supplementary Appeal for IDPs in Colombia: Protection and durable solutions for IDPs in Colombia" (United Nations High Commissioner for Refugees, 2007), 2; P. Weiss Fagen, A. Juan, F. Stepputat, and R. Lopez, "Internal Displacement in Colombia: National and International Responses," ISS/IG. Kongevej Working Paper (Copenhagen: Institute for International Studies, 2003), 16.

4. J. Ferguson, The Anti-politics Machine: 'Development,' Depoliticization and Democratic Power in Lesotho (Cambridge: Cambridge University Press, 1990); L. Malkki, "Speechless Emissaries: Refugees, Humanitarianism and Dehistoricization," Cultural Anthropology 11, no. 2 (1996): 377-404.

5. R. Thorp, Progress, Poverty and Exclusion: An Economic History of Latin America in the $20^{\text {th }}$ Century (Washington, D.C.: Inter-American Development Bank, 1998).

6. C. Kay, "Reflections on Rural Violence in Latin America," Third World Quarterly 22, no. 5 (2001): 741-775.

7. Ibid.

8. H. T. Braun, "Que haiga paz!" The Cultural Contexts of Conflict in Colombia [Let There be Peace! (...)], In Peace, Democracy, and Human Rights in Colombia, ed. C. Welna and G. Gallón (Notre Dame, IN: University of Notre Dame Press, 2007), 23-59; F. S. Gutierrez, "Internal Conflict, Terrorism and Crime in Colombia," Journal of International Development 18, no. 1 (2006): 137-150; M. Palacios and F. Safford, Colombia. Pais Fragmentado, Sociedad Dividida [Colombia: Fragmented Country, Divided Society] (Bogotá: Editorial Norma SA, 2002).

9. Comisión Colombiana de Juristas (CCJ), (2006) Revertir el destierro forzado: protección y restitución de los territorios

(c) Ellen Fadnes and Cindy Horst, 2009. This open-access work is licensed under a Creative Commons Attribution-NonCommercial 4.0 International License, which permits use, reproduction and distribution in any medium for non-commercial purposes, provided the original author(s) are credited and the original publication in Refuge: Canada's Journal on Refugees is cited. 
usurpados. Obstáculos y desafíos para garantizar el derecho al patrimonio de la población desplazada en Colombia, 2006; G. Gallón (2007) Human Rights: A Path to Democracy and Peace in Colombia, in Peace, Democracy, and Human Rights in Colombia (see note 8).

10. Comisión Colombiana de Juristas (CCJ).

11. Comisión Colombiana de Juristas (CCJ); A. M. Ibáñez and P. Querubín, Acceso a Teirras y Desplazamiento Forzado en Colombia. Documento Cede (Universidad de los Andes, 2004).

12. Names are changed in order to respect the privacy of informants.

13. R. Muggah, “Through the Developmentalist's Looking Glass: Conflict-Induced Displacement and Involuntary Resettlement in Colombia," Journal of Refugee Studies 13, no. 2 (2000): 138.

14. Braun; L. Obregón and M. Stavropoulou, "In Search of Hope: The Plight of Displaced Colombians," In Cohen, R. \& Deng, F. M. (eds.) The Forsaken People: Case Studies of the Internally Displaced (Washington, DC: Brookings Institution Press, 1998).

15. Braun.

16. Ibid.

17. "Rosa Aguilar" (R.A)., indigenous displaced woman, interviewed July 17, 2007, in Bogotá, at the conference marking the ten years of Law 387.

18. "Una propuesta para la crisis," Semana, February 10, 2008, <http://www.semana.com/wf_InfoArticulo.aspx? idArt=111301 $>$ (accessed June 12, 2008).

19. Weiss Fagen, Juan, Stepputat, and Lopez.

20. Office of the High Commissioner for Human Rights (OHCHR), Mission to Colombia, Report of the Representative of the Secretary-General on the human rights of internally displaced persons, Walter Kälin (Human Rights Council, 2007), 8.

21. Congress of the Republic of Colombia (COC), Ley 387 de 1997: Del Desplazado y de la Responsibilidad del Estado [Law 387 of 1997: On the Displaced and the Responsibility of the State], art. 3 (1997).

22. Weiss Fagen, Juan, Stepputat, and Lopez.

23. M. J. E. Cepeda, "How far may Colombia's constitutional court go to protect IDP rights?" Forced Migration Review (Special issue, December 2006): 2.

24. Corte Constituciónal de Colombia (CC), Sentencia T-025/2004.

25. Ibid.

26. Ibid.; also IDMC, Colombia. New displacement continues, response still ineffective. Country report (2009).

27. OHCHR, Mission to Colombia, Report of the Representative of the Secretary-General on the human rights of internally displaced persons, Walter Kälin (Human Rights Council, 2007).

28. COC, Ley 387 de 1997 [Law 387 of 1997], art. 4.

29. Acción Social (officially: Agencia Presidencial para la Acción Social y la Cooperación Internaciónal) is a governmental entity established in order to channel and coordinate national and international resources to implement social programs assisting vulnerable groups in society, including IDPs.

30. Consultoríaparalos Derechos HumanosyelDesplazamiento (CODHES), Más o menos desplazados [Consultancy for Human Rights and Displacement, More or Less Displaced], Boletín de la Consultoría para los Derechos Humanos y el Desplazamiento, No. 69 (Bogotá D.C., 2006); OHCHR, Mission to Colombia, Report of the Representative of the Secretary-General on the human rights of internally displaced persons, Walter Kälin (Human Rights Council, 2007); Weiss Fagen, Juan, Stepputat, and Lopez.

31. OHCHR, Mission to Colombia, Report of the Representative of the Secretary-General on the human rights of internally displaced persons, Walter Kälin (Human Rights Council, 2007).

32. Ibid.

33. COC, Ley 387 de 1997 [Law 387 of 1997], art. 13.

34. COC, Ley 387 de 1997]; A. M. Ibáñez and P. Querubín.

35. Corte Constituciónal de Colombia (CC), Sentencia C-278/2007.

36. M. Romero, "Year of Displaced People's Rights in Colombia," Forced Migration Review 29 (2007): 58.

37. MCPP is a commission established in 2005 to follow up on the 2004 sentence from the Constitutional Court, comprised by the research institute CODHES, the faculty of law at the Andes University, the former President of the Constitutional Court, and a number of representatives from the civil society; see <http://www.codhes.org/index. php?option=com_content\&task=view\&id=39\&Itemid=52>.

38. Comición de Seguimiento a la Política Pública Sobre el Desplazamiento Forzado [Monitoring Commission for the Public Policies on Internal Displacement, MCPP], Proceso Nacional de Verificación de los Derechos de la Población Desplazada, 2008, 132.

39. A. M. Ibáñez and A. Moya, La población desplazada en Colombia: Examen de sus condiciones socioeconómicas y análysis de las politicas actuales [The displaced population in Colombia: an assessment of their socioeconomic conditions and analysis of the current politics], Report commissioned by Misión para el diseño de una estrategia para la reduccion de la pobreza y la desigualdad (MERPD) [The Mission for the design of a strategy to reduce poverty and inequality], 2007.

40. COC, Ley 387 de 1997 [Law 387 of 1997], art. 19.

41. Ibáñez and Moya.

42. Weiss Fagen, Juan, Stepputat, and Lopez .

43. OHCHR, Mission to Colombia, Report of the Representative of the Secretary-General on the human rights of internally displaced persons, Walter Kälin (Human Rights Council, 2007).

44. “Tierras destinadas a víctimas del conflicto serán dadas a particulares por MinAgricultura e Incoder" [Land intended for victims of the conflict will be given to private persons by the 
Ministry of Agriculture and Incoder], El Tiempo, February 10, 2008, <http://www.eltiempo.com/justicia/2008-02-10/ ARTICULO-WEB-NOTA_INTERIOR-3952909.html> (accessed February 12, 2008).

45. IDMC.

46. E. Ross, "Clearance as Development Strategy in Rural Colombia," Peace Review: A Journal of Social Justice 19 (2007): 59-65.

47. IDMC.

48. R. Hill, K. Jorgensen Diener, S. Miller, and T. White, "IDP Livelihoods and Personal Security: Case Studies from Colombia and Sudan," Refugee Survey Quarterly 25, no. 2: (2006): 49 .

49. Malkki, 378 .

50. B. Chimni, "Globalization, Humanitarianism and the Erosion of Refugee Protection," Journal of Refugee Studies 13, no. 3 (2000): 243-263; B. Harrell-Bond, E. Voutira, and M. Leopold, "Counting the Refugees: Gifts, Givers, Patrons and Clients," Journal of Refugee Studies 5, no. 3/4 (1992): 206-225; C. Horst, Transnational Nomads. How Somalis Cope with Refugee Life in the Dadaab Camps of Kenya (Oxford: Berghahn Books, 2006), 112; J. Schrijvers, "Dilemmas of Humanitarian Aid: Supporting Internal Refugees in Sri Lanka, in Refugees and the Transformation of Societies: Agency, Policies, Ethics and Politics, ed. P. Essed, G. Frerks, J. Schrijvers (Oxford and New York: Berghahn Books, 2004).

51. Ferguson; W. F. Fisher, "Doing Good? The Politics and Antipolitics of NGO Practices," Annual Review of Anthropology 26 (1997): 439-464.

52. Malkki, 398.

53. A. Mason, "Colombia's Democratic Security Agenda: Public Order in the Security Tripod," Security Dialogue 34, no. 4 (2003): 391-409.

54. Luis Carlos Restrepo Ramírez, the High Commissioner for Peace, "Conflicto armado a amenaza terrorista?" (Government of the Republic of Colombia, 2005).

55. "Bayron Castillo" (B.C), displaced man interviewed in Puente Aranda, Bogotá, July 27, 2007, at one of the centres for IDP registration (Unidad de Atención y Orientación de Pte. Aranda).

56. G. Duncan, Los señores de la Guerra: De paramilitares, Mafiosos y Autodefensas en Colombia [The Lords of the
War: On Paramilitaries, Mafia and Self-Defence groups in Colombia] (Bogot: Editorial Planeta Colombiana S.A., 2006).

57. Ferguson.

58. Malkki, 398.

59. P. K. Rajaram, "Humanitarianism and Representations of the Refugee," Journal of Refugee Studies 15, no. 3 (2002): 247-264.

60. International Press Institute (IPI), World Press Freedom Review, 2006.

61. IPI; Reporters Without Borders (RWB), Colombia - Annual Report 2008.

62. In June 2007, eleven diputados (Members of Parliament) who had been prisoners of FARC for more than five years were killed in crossfire. FARC hesitated to hand over the corpses, an event which received extensive media coverage for weeks.

63. Hill, Jorgensen Diener, Miller, and White.

64. C. Brun, "Local Citizens or Internally Displaced Persons? Dilemmas of Long Term Displacement in Sri Lanka," Journal of Refugee Studies 16, no. 4 (2003): 376.

65. T. Weiss, "Internal Exiles: What Next for Internally Displaced Persons," Third World Quarterly 24, no. 3 (2003): 442.

66. R. Cohen, Response to Hathaway, Journal of Refugee Studies 20, no. 3(3): 370-376.

67. J. C. Hathaway, "Forced Migration Studies: Could We Agree Just to 'Date'?" Journal of Refugee Studies, 20, no. 3 (2007): 349-369. For the full debate on this issue, see Journal of Refugee Studies 20, no. 3 (2007): 349-390.

Ellen Fadnes wrote her master's thesis in development studies on Internally Displaced Persons (IDPs) in Colombia in 2008, while she was an intern at the Peace Research Institute Oslo (PRIO). She currently works for the Norwegian Ministry of Foreign Affairs.

Cindy Horst is a senior researcher at the Peace Research Institute Oslo (PRIO). She has worked on issues relating to forced migration for many years, focusing mainly on the transnational engagements of refugees. 